症例

若年女性にみられた肝転移合併，膵 solid cystic tumor の 1 例

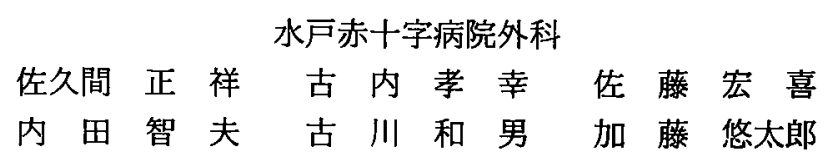

17歳女性に発生した肝転移合併, 膵 solid cystic tumor（以下SCT）を経験したのて 報告する. 主訴は左上腹部膨隆. 腹部超音波検査, CT, MRIにて䐁尾部の被膜を有する 充実性,一部蓑胞性の約 $12 \mathrm{~cm}$ 径の腫瘤であった。同時に肝 $\mathrm{S}_{4}$ から $\mathrm{S}_{5}$ にかけ約 $6 \mathrm{~cm}$ 径の 腫瘤を認めた。腹部血管造影ではいずれも hypervascular mass であった。 脾温存膵尾部 切除, 肝部分切除を行った. 病理組織学的に SCT と診断された. 被膜浸潤は認めたもの の，核異型は著明ではなかった．若年女性で肝転移を有する SCT は極めて稀である. 生 物学的悪性度が低いといわれるので, 肝転移を有するSCT に対して積極的な切除が勧 められる。

索引用語：脺 solid cystic tumor, 肝転移

緒言

膵の solid cystic tumor (SCT) は若年女性に好発 し，予後良好な腫瘍といわれている。しかし，症例が 集積されるにつれ，悪性例もみられるようになってき $た^{1)}$.

今回われわれは，17歳女性に発生した肝転移合併 SCT 経験したので若干の文献的検討を加え報告す る.

患者：17歳，女性.

\section{症例}

\section{主訴：左上腹部膨隆。}

既往歴：気管支喘息, 内服治療中。

家族歴：特記すべきことなし。

現病歴: 平成 6 年 4 月初め, 左上腹部膨隆を自覚し 近医受診。腹部超音波検查にて左上腹部に約 $10 \mathrm{~cm}$ 大 の腫瘤を指摘され，当科を受診. 平成 6 年 4 月 25 日精 㚗，手術目的で入院となった。

入院時現症：身長 $169 \mathrm{~cm}$, 体重 $66 \mathrm{~kg}$, 血圧 $112 / 64$ $\mathrm{mmHg}$, 栄責状態は良好で, 眼瞼結膜に黄疸なく, 眼 球結膜に筫血を認めず，表在りンパ節も触知しなかっ た. 胸部所見に異常を認めなかった. 腹部所見では, 左上腹部に弾性軟, 手拳大の腫瘤を触知し, 右側臥位 では膨隆を認めた。

1995年 4 月 17 日受付 1995 年 7 月 19 日採用
入院時検查成績 : WBC $8,000 / \mathrm{mm}^{3}, \mathrm{Hb} 13.4 \mathrm{~g} / \mathrm{dl}$, PLT $21.7 \times 10^{4} \mathrm{~mm}^{3}$, TP $8.2 \mathrm{~g} / \mathrm{dl}$, TB $0.63 \mathrm{mg} / \mathrm{dl}$, GOT 14IU/L, GPT 8IU/L, LDH 292IU/L, S-AMY 94IU/L, BUN 9mg/dl, Cr $0.7 \mathrm{mg} / \mathrm{dl}$, CEA $1.0 \mathrm{ng} /$ $\mathrm{ml}, \mathrm{CA} 19-926.2 \mathrm{U} / \mathrm{ml}$.

腹部超音波検査 : 左上腹部に内部エコーレベルの不 均一な, 一部暴胞状の径 $12 \mathrm{~cm}$ の腫瘤を認めた。肝 $\mathrm{S}$ ，氻 ら $\mathrm{S}_{5}$ にかけ, 内部エコーレベル不均一な $6 \mathrm{~cm}$ 径の瘇痹 もみられた（図 1)。

腹部 CT 所見：胃後方膵尾部に $12 \mathrm{~cm}$ 大の腫嘴を認 め，単純，造影ともに低吸収域であった。また，造影 CTにて内部に壊死と思われる低吸収域が著明となっ た。肝 $\mathrm{S}_{4}, \mathrm{~S}_{5}$ にも低吸収域を認めた（図 2)。

MRI 所見：膵尾部に内部構造の不均一な被膜を有 する腫瘤を認めた。腫瘍内に $\mathrm{T}_{1}$ 強調, $\mathrm{T}_{2}$ 強調ともに出 血，壊死と考えられる高信号域を認めた（図 3 ).

内視鏡的逆行性䐙管造影：膵体部から尾部にかけ主 膵管は前下方に圧排, 偏位していた。

腹部血管造影：脾動脈が頭側へ圧排されており，膵 体部から尾部に巨大な hypervascular mass が認めら れた。膵背動脈が栄養血管と思われた．肝内側区域に も CTに一致して hypervascular mass がみられ, 静 脈相で輪状の謷染を認め, 転移が疑われた（図 4). 以上より, 肝転移を伴った膵尾部の SCT と診断し た. 

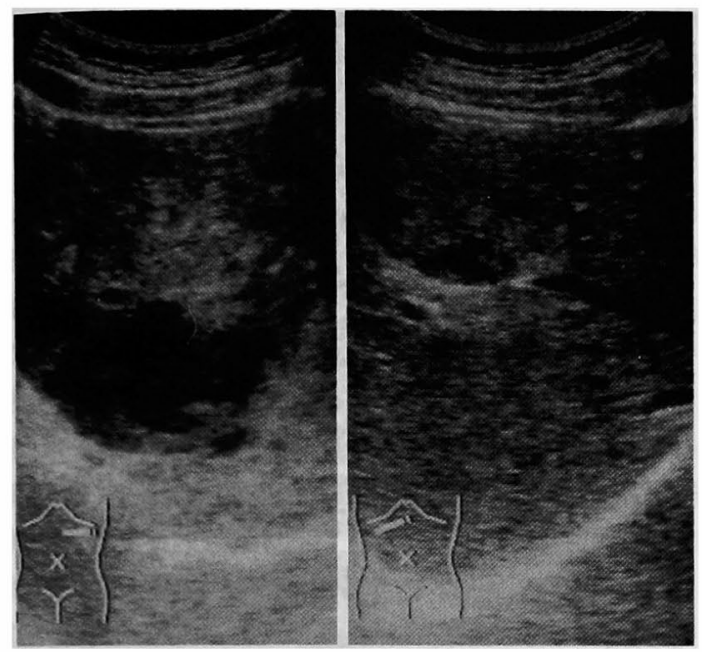

図 1 腹部超音波像 : 左図, 膵尾部の售胞性病変. 右 図, 肝腫瘤。
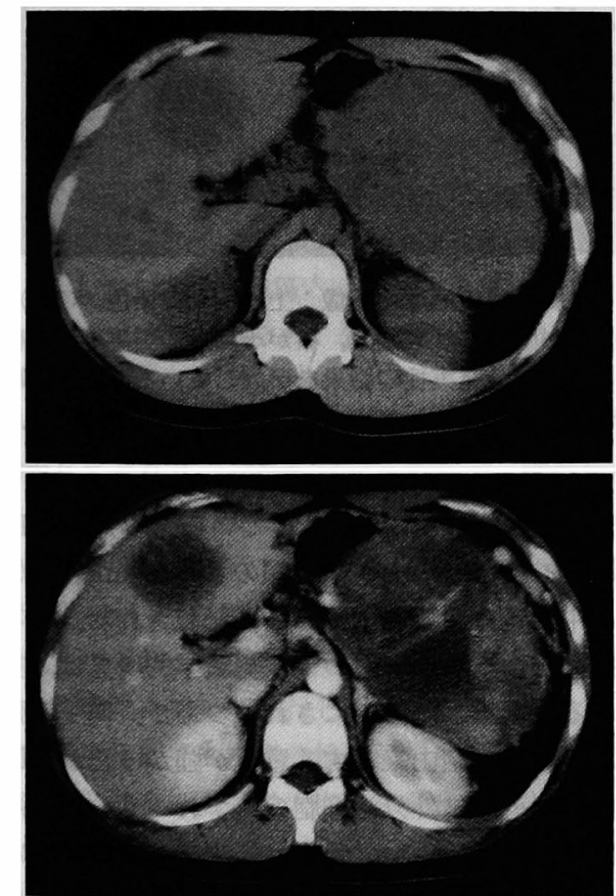

図2 腹部 CT 所見：(上段：単純像,下段：造影像) 膵尾部に巨大な腫瘤を認め, 単純造影ともに低吸収 域であった。肝にも同様の腫瘤を, 認めた。

手術所見：膵尾部より発生した薄い被膜を有する充 実性,一部蘘胞性の径 $10 \mathrm{~cm}$ 大の腫瘍を認めた. 脾動脈 は腫瘍の上後方で3〜 4cm にわたり被膜内を走行して
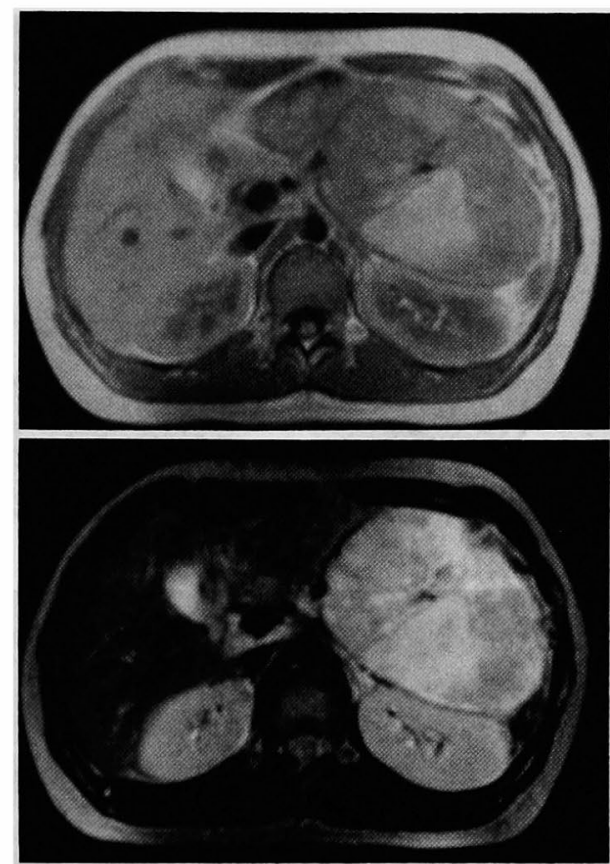

図 3 MRI 所見: (上段: $T_{1}$ 強調像, 下段: $T_{2}$ 強調 像）腫㳻内に $\mathrm{T}_{1}, \mathrm{~T}_{2}$ ともに出血, 壊死と考元られる 高信号域を認める。

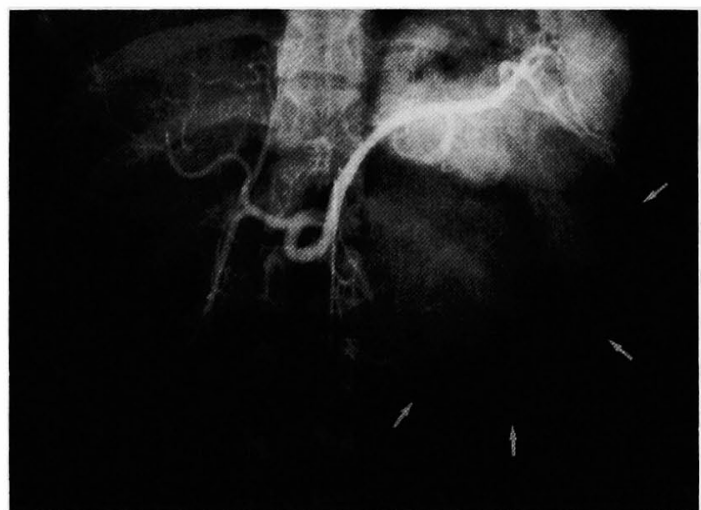

図 4 腹部血管造影：脾動脈が上方へ压排されてお り，膵体部から尾部に巨大な hypervascular mass が認められる。

おり, 脾門部で切離し, 脾温存, 膵尾部切除を施行し た。術中エコーで肝腫瘍は $\mathrm{S}_{4}, \mathrm{~S}_{5}$ にまたがっており， 肝部分切除を施行した. 手術診断は, $\mathrm{H}_{1}, \mathrm{P}_{0}, \mathrm{~S}_{0}, \mathrm{~N}_{0}$, $\mathrm{RP}_{0}, \mathrm{CH}_{0}, \mathrm{DU}_{0}, \mathrm{PV}, \mathrm{A}_{0}, \mathrm{PL}(-)$ であった.

切除標本：膵腫湯は $12 \times 10 \times 9 \mathrm{~cm}$ で内部に出血, 壊 死を伴う充実性の腫瘍であった。肝腫瘍も膵腫場に類 

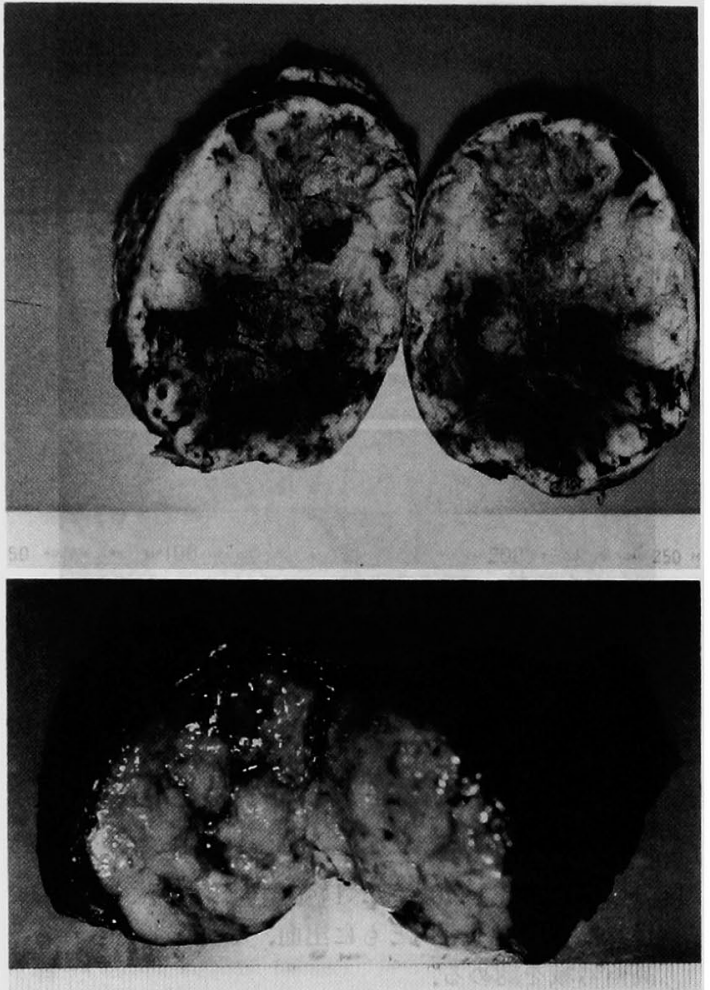

図 5 摘出標本の割面：上段, 膵腫畼は内部に出血, 壊死を伴う充実性の腫瘍であった。下段，肝腫㖴。

\section{似しており，転移と考えられた（図 5).}

病理組織学的所見：膵腫瘍, 肝腫湟とも, 胞体が明 るく好酸性で, 核が小円形の腫湯細胞を有し, 大部分 充実性の胞巣を形成している.膵では被膜浸潤がみら れた(図 6 上). 肝は転移と診断された。兔疫組織化学 的検索では $\alpha_{1}$-antitrypsin 陽性で，各種膵ホルモンに 対しては陰性であった. 電顕所見では, zymogen 様顆 粒を認めたが，神経内分泌顆粒はみられなかった（図 6 下).

以上より組織学的にも肝転移を伴う SCT と診断さ れた。

術後経過：患者は術後約 10 力月で, 再発の兆候はな w.

\section{考 察}

SCT は若年女性に好発する極めて悪性度の低い腫 瘍であるとされ，近年多くの報告がなされている.1959 年 Franz $z^{2}$ が papillary tumor of the pancreas と報告 したのに始まり，その後種々の名称でいわれ，現在で は Klöppel, 諸星ら ${ }^{3)} の$ solid and cystic tumor of the

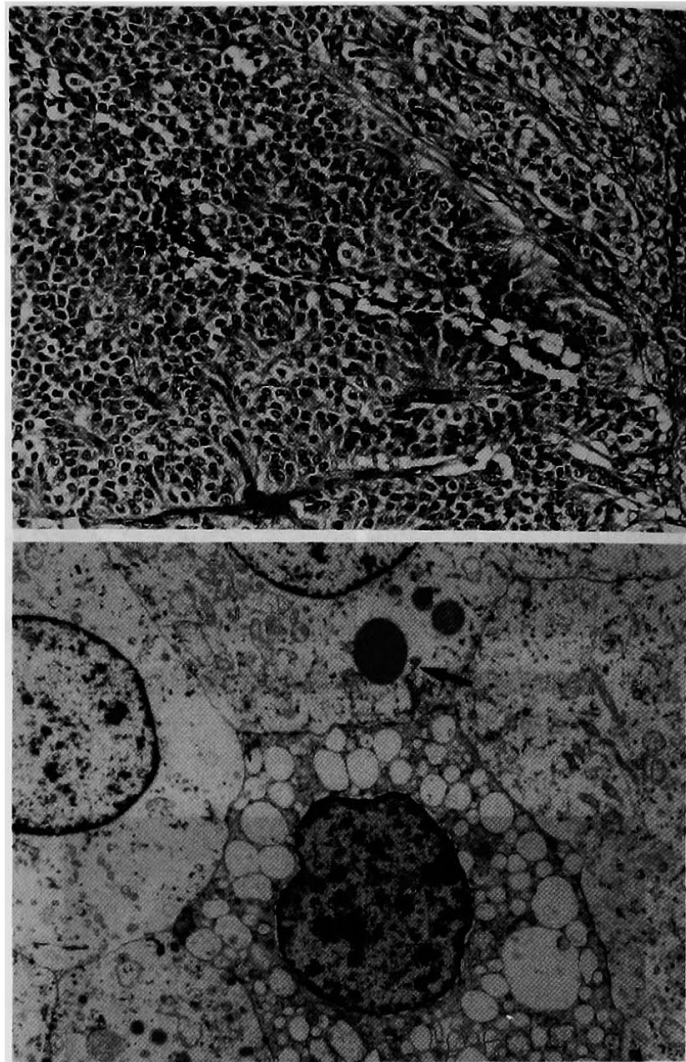

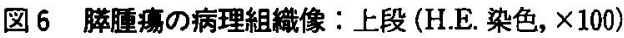
胞体が明るく好酸性で, 核が小円形の腫瘍細胞を有 し，大部分充実性の胞巣を形成している. 下段（電 影像, $\times 5,000)$ zymogen 様影粒（矢印）を訆める.

pancreas が一般的に用いられている. 本邦でも1986 年, 脺癌取り扱い規約組織分類の miscellaneous な脺 腫瘍の中に新たな疾患単位として記載された。

腫瘍の画像診断の特徵および組織学的所見は, 多彩 ではあるが次第に明らかにされつつある，発生起源に ついても腺房細胞由来とする意見が強かったが，最近 では内分泌或いは外分泌細胞のいずれへも分化し得る stem cell 或いは primordial cell 由来とする考えに変 わりつつある4.一方，報告の集積に伴い高齢者にも発 生することがいわれ, malignant potential が問題とさ れてきた。悪性化の所見として周囲臟器浸潤, リンパ 節転移，遠隔転移，局所再発などの臨床所見と，組織 学的な被膜浸潤，血管侵襲などがあげられる。浅利ら は本邦報告139例を検討し,55例に浸潤があったとして いる. 被膜へ10例 $16.7 \%$ ，膵臓への浸潤13例 $21.7 \%$, 十二指腸 3 例 $5.0 \%$, 門脈, 肝動脈へ 2 例 $5.0 \%$ と報告 
している。，一方，野口ら6にによる102例の検討では36例 (35.5\%)が悪性とされ，稀なものではない。被膜浸潤 13例, 周囲臟器への浸潤17例, 肝転移 5 例, 局所再発 1例がみられたとしている．肝転移については1994年 12月まてに本邦及び欧米の文献上16例の報告があ

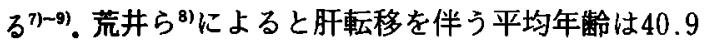
歳であり，若年発症を特徵とする SCT の平均年齢 24.6歳と比較して高龄であった．肝転移例に高齢者が 多いことは，腫瘍の成長に伴い悪性化する可能性を示 唆している. 肝転移を SCT と同時に切除した最初の 報告は小川ら の例で, 50 歳女性の多発性肝転移, 大網 転移を有する膆体尾部の SCT である．膵体尾部脾切 除,拉大右葉切除, 大網切除を行い, 肝動注リザーバー, 腹腔へチューブを留置し術後化学㙩法も行い，1年 2 カ月生存しているという.

本症例は病理組織学的に核のクロマチンが目立つも のの, 異型性はなかった. 西原ら ${ }^{10)}$ は組織学的悪性度の 指標として静脈浸潤，高度の核異型などをあげている が, SCT が slow growing tumor であることと, 長期 経過観察も必要であることから必ずしも悪性度が臨床 所見と一致しない. DNA ploidy patternでは，転移を 有する症例は aneuploidであったことから，これが SCT の予後因子の一つとなり得るという報告もみら れる ${ }^{11}$. しかし, 同一腫瘍内でも DNA ploidy pattern は heterogeneity がみられ，悪性度と合致しないとい われる゙.

術式として本症例では，若年者であること，腫瘍と 脾か雁れておりリンパ節転移がみられず，脾静脈の副 血行路が発達していたことより, 脾を温存し膵尾部切 除, 肝部分切除を施行した. 脾を温存する免疫学的意 義，SCTではリンパ節転移が少ないことなどから，こ の術式を行った。脾温存, 脾動静脈を切離し膵体尾部 切除を脺㐮胞に対して施行した報告もある ${ }^{12)}$. 本症例 も術後経過良好で血夜学的検查所見に異常を認めず, 術後の CT 検査でも脾の大きさに変化はみられなかっ た.

SCT が低悪性度であることから，肝転移などの遠隔 転移に対しても積極的な切除が勧められる。

\section{結語}

17歳女性に発生した肝転移合併，脺尾部 SCTに対 し, 脾動静脈切離, 脾温存膵尾部切除, 肝部分切除を 施行した. SCT の悪性化，特に肝転移につき若干の文 献的検討を加え報告した。

\section{文 献}

1）小西二三男, 松能久雄：膵真性业胞の病理診断・分 類の問題点-Solid and Cystic Tumor および類 縁疾患. 胆と膵 $11: 25-31,1990$

2) Franz VK: Tumor of the pancreas. Atlas of Tumor Pathology VII, Fasc, 27 and 38. Armed Forces Institute of Pathology, Washington DC, 1959, p32-33

3) Klöppel G, Morohoshi T, Johm HD, et al : Solid and cystic acinar cell tumor of the pancreas. A tumor in young women with favorable prognosis. Virchow Arch Pathol Anat 392: 171 $-183,1981$

4) Morrison DM, Jewell LD, McCaughey WTE, et al: Papillary cystic tumor of the pancreas. Arch Pathol Lab Med 108: 723-727, 1984

5）浅利靖, 島津盛一, 西村博行他：巨大な脺 solid and cystic tumor $\sigma 1$ 症例. 日消外会誌 24 : 2461-2465, 1991

6）野口 徹, 工藤道也, 原田晴久他 : 膵の Solid and Cystic Tumor の 2 例一本邦報告102例の検討も加 えて一。臨外医会誌 $51: 1562-1567,1990$

7) Ogawa $T$, Isaji $S$, Okamura $K$, et al : A case of radical resection for solid cystic tumor of the pancreas with widespread metastasis in the liver and greater omentum. Am J Gastroenterol $88: 1436-1439,1993$

8）荒井謙一, 森田ゆかり, 森合哲也他：肝転移を伴っ た膵のSolid Cystic Tumorの 1 例 - Flow cytometryによる検討を加えて一. 膵㵴 $9: 375$ $-381,1994$

9）武川 悟,三井照夫, 芦沢一喜他：肝転移を伴った Solid and Cystic Tumor(以下 SCT) の 1 例. 膵 蔵 $7: 361,1992$

10) Nishihara $K$, Nagoshi $M$, Tsuneyoshi $M$, et al : Papillary cystic tumor of the pancreas. Assessment of their malignant potential. Cancer 71 : $82-92,1993$

11）松野久能, 小西二三男, 石川義麿他: Papillarycystic Neoplasm of the Pancreas $の$ 臨床病理学 的検討。胆と脺 $7: 1293-1302,1986$

12）須藤骖章, 宮本正章, 河村正生他：脾温存, 膵体尾 部切除術を伴った脺劉胞症 3 症例. 膵臓 $6: 162$ $-166,1991$ 


\title{
A CASE OF SOLID CYSTIC TUMOR OF THE PANCREAS WITH LIVER METASTASIS IN A YOUNG FEMALE
}

\author{
Masayoshi SAKUMA, Takayuki FURUUCHI, Hiroki SATO, Norio UCHIDA, \\ Kazuo FURUKAWA and Yutaro KATO \\ Department of Surgery, Mito Red Cross Hospital
}

We report a case of solid cystic tumor of the pancreas (SCT) with liver metastasis which occurred in a 17-year-old female. The chief complaint was distension in the left upper abdomen. Abdominal ultrasonography, CT scan and MRI revealed a solid, partially cystic encapsulated tumor about $12 \mathrm{~cm}$ in diameter in the tail of the pancreas. Also, image examination visualized a liver tumor about $6 \mathrm{~cm}$ in diameter extending over the segment IV and V. Abdominal angiography showed hypervascularization in both tumors. Distal pancreatectomy with preservation of the spleen and partial liver resection were performed. Histologically the pancreatic tumor was diagnosed as SCT, and the liver tumor was metastatic. Capsular invasion was found, but nuclear atypism was not remarkable. SCT with liver metastasis rarely occurs in young females. It is recommended that SCT with liver metastasis should be resected aggressively, as this tumor exhibits a biologically low grade of malignancy. 